\title{
Political modernization theory: criticisms of democratic transition theorists
}

UDC 321.7-048.35:303.833.6

DOI https://doi.org/10.24195/2414-

9616.2020-5.13

Mustafa Nezar Harb

Postgraduate Student at the Department of Political Science

V. N. Karazin Kharkiv National University Svobody sq., 4, Kharkiv, Ukraine

\begin{abstract}
The link between modernization theory and democracy originates from Lipset in his article "Some Social Requisites of Democracy: Economic Development and Political Development" in 1959. Lipset hypothesized that as societies develop economically, their citizens no longer tolerate repressive political regimes. The rise in per capita GDP, he argued, triggers a transition to democracy. Modernization theory considers that the economic field is related to public policy as one of its most important applications. The theory assumes that third world countries are poor and traditional, and the western countries are rich and modern. And it sets a clear course of development for those poor countries in the third world to follow, based on western values, aiming to increase the living standards of the poor. This creates a state of dependency on poor countries to rich countries. Modernization theory prerequisites for democracy demand the third world countries a high level of modernization, urbanization, expansion of the middle class, and democratic culture for the general public, in order to gain a modern democratic political system. Democratic transition theorists criticize this theory and its prerequisites for democracy as it is difficult for some nations to apply these prerequisites. This article focuses on analyzing the logic of modernization theory, its definitions, origins, and requirements for a modern democratic society. It views upon the modernization theory and its prerequisites for democracy by reviewing the literature on the relations between socio-economic development and political democracy. It also concentrates on some criticism of this theory made by democratic transition scientists. The contemporary political science has faced much criticisms by transit study's theorists (Arab scientists included) due to the difficulty of applying the prerequisites of transition from traditional to modern societies to reach a stable democratic system.

Key words: modernization theory, prerequisites of modernization, transfer to democracy, criticism of modernization theory, stable democratic system.
\end{abstract}

Introduction. Modernization theory has been one of the major perspectives in the study of national development since the 1950s. This theory is concerned with the process of transferring from traditional to a modern society. Political scientists primarily from Europe and the United States such as Barrington Moor, Martin Lipset, Walt Rostow, and others, made an important contribution in studying the process of modernization in order to understand and explain the economic development in different countries. Their works paid the attention to the characterization of the relationships between economic development and democratization.

Purpose and objectives. The aim of this article is to present the concept of modernization theory and its requirements for reaching democracy and examine the criticisms that have been directed at it by some theorists of the democratic transition.

Research methods. The theoretical framework of modernization theory analysis is based on historical, comparative, analytical and some other methods.

What is modernization theory and its origins?

According to Jonathan Westover, "modernization theory is a description and explanation of the processes of transformation from traditional or underdeveloped societies to modern societies and looks at the economic growth within societies" [1, p. 115]. The theory seeks to identify the social variables that contribute to social progress and development in different countries, and to explain the process of social transformations. Modernization theory does not only emphasize the process of change, but it considers the responses to that change. It also looks at internal dynamics with reference to social and cultural structures and adaptations to new technologies.

The origin of modernization theory can be traced to the response of American political elites and intellectuals to the international setting of the post-Second World War era, particularly during the cold war period [2]. Most of the modern social and human sciences in Europe and North America can be summed up as a study of this transition (from traditional society to a modern one) by Karl Marx, Max Weber, Émile Durkheim and their successors. Practically all theories related to modernization, study the transition of society from the traditional state to modernity with differences in the understanding of the structure of this transition, the essence of modern society, characteristics of traditional society, and views about the positive and negative effects of this transition. While their specific ideas on religion, education, politics etc. have been a source of much interest, it is their general theories of social change that have attracted most attention and inspired the emergence of the "sociology of development" in the twentieth century [3, p. 41-42].

According to Alvin So, there are three main historical events that were favorable to the inception of the modernization theory [4, p. 17-23]. First, the rise of the United States as a superpower after WWII. Second, the emergence of new third world nation-states in the wake of the disintegration of the European colonial empires in Asia, Africa, 
and Latin America. These nascent nation-states were in search of a model of development to promote their economy and to enhance their political independence [5, p. 32-34, 56-9]. Third, the spread of the world communist movement and the world split into two camps: communist and capitalist, which led to the emergence of the Cold War.

Prerequisites of modernization theory for democracy

Many researchers and scientists such as Martin Lipset, Robert Dal, Barrington Moore, and others began their studies of the democratic transition through the focus of the modernization theory in order to explain the democratic system and to explore the confrontation in the socialist camp. An attempt to directly link modernization theory with democracy was made in the famous article by Martin Lipset in 1959 "Some Social Requisites of Democracy: Economic Development and Political Development" [6, p. 69-105], where he addresses the possible role of economic development in the democratization of the third world countries. In his attempt to link the level of development of a country and its probability of being democratic, he refers to the extremely high correlation between aspects of social structure, such as income, education, religion, on the one hand, and democracy, on the other.

In his article, he presented the social and economic requirements of democracy such as urbanization, wealth, education, the size of the middle class, industrialization, and the degree of education in the community. On the other hand, he proposed the idea of legitimacy, in the sense of the political system's ability to generate ideas more suitable for society and more appropriate to solve its deep problems. Lipsett made a hypothesis that the more developed a country is economically, the more likely that the country would be a democracy and be characterized by a more stable political situation overall. [6, p. 70-72].

Other researchers such as $B$. Moore related democratization to the rise of the middle class and to the terms of its political incorporation [8]. Social sociologist Alex Inkeles, discusses the consequences

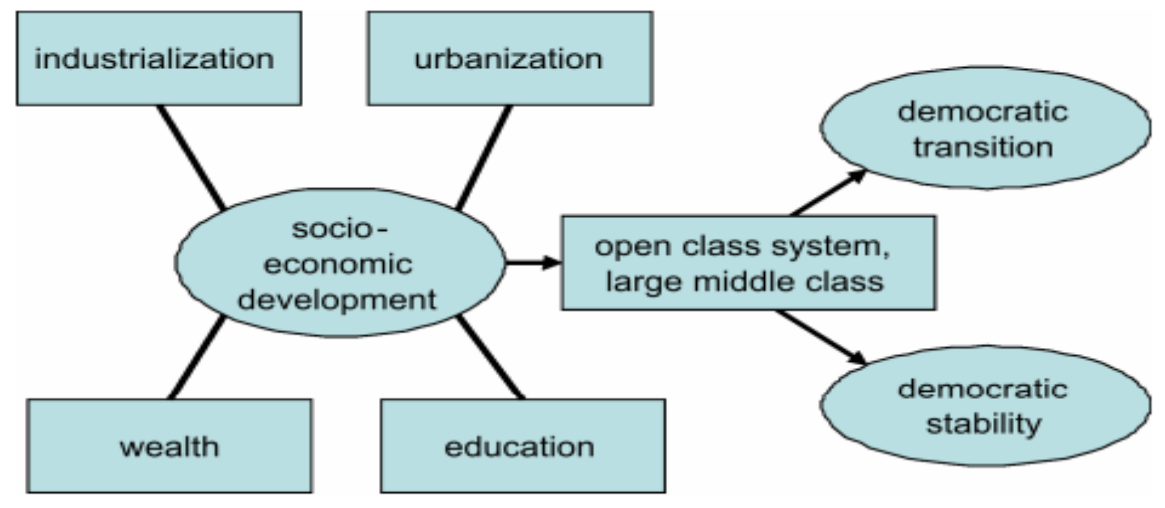

Figure 1. Modernization Theory according to Lipset

Source: $[7, p .2]$ of the modernization process for individual attitudes and behavior. As for Adam Przeworski and his co-authors, they argued that countries may become democratic due to reasons unrelated to their level of economic development [9, p. 39-55]. Once prosperous, however, democracies with higher levels of GDP per capita were to avoid slipping back into autocracy, then over time the relationship between GDP and democracy would emerge. It would be so even if economic growth does not lead to democratization.

Modernization theory considers that the economic field is related to public policy as one of its most important applications. W. Rostow presents five stages of economic development, which are: 1. Traditional society. 2. Precondition for takeoff. 3. The takeoff process. 4. The drive to maturity. 5. The age of high mass consumption society. According to this exposition, Rostow's model illustrates his desire to promoted a development model to assist lower-income countries in the development process by providing capital, technology, and expertise [10, p. 3-13]. The U.S foreign policy was influenced by Rostow's political theories when it adopted the Marshall plan as alliance for progress in Latin America countries. It was aimed not only at the development of these countries, but also at the assertion the United States' influence over communist Russia. Rostow argues that economic development will be achieved when a country has high industrial productivities and exports goods to the rest of the world.

Modernization theory assumes that third world countries are poor and traditional, and the western countries are rich and modern. And it sets a clear course of development for those poor countries in the third world to follow, based on the western values, aiming to increase living standards of the poor. In this context, the third world countries have to look up to rich countries such as U.S.A and Europe as their model for economic prosperity and democratic stability. This creates a state of dependency of poor countries from the rich states. Once poor countries come into contact with the western countries, they will not be able to resist the temptation toward modernization.

In summary, modernization theory attempts to identify the social variables that contribute to social progress and the development of societies and seeks to explain the process of social development. The theory deals with internal dynamics with reference to social and cultural structures and adaptation to new technologies. Modernization theory by nature is a homogenizing process that produces inclinations toward resemblance among societies. It is based on 
optimistic economic growth models. The western countries that are economically rich serve as a model for this theory. And the poor countries are believed to be in their initial state of economic growth. The theory proponents focus on choosing the right techniques and technologies designed by western countries to achieve industrialization in the poor countries. They emphasize the importance of lending capitalist values.

Criticism of modernization theory by democratic transition scientists

Modernization theory was popular in the 1960s but came under heavy attack in the beginning of the 1970s. During the 1970s, a very important phenomenon occurred in Southern Europe when Greece, Portugal, and Spain transition to democracy. Then a wave of democratic transfers began in Latin America and later in the rest of the world. These transitions were accompanied by new scientific works of political scientists. Among these scientists were a group of researchers headed by G. O'Donnell, P. Schmitter and L. Whithead, who edited and published four volume edition "Transitions from Authoritarian Rule: Comparative Perspectives" in 1986 which has been used later as a paradigm for transitology. Also, researchers such as J. Linz, A. Stepan, J. Higly, T. Karl and others made a great contribution into the development of this theory.

Guillermo O'Donnell and other transitology scientists criticized the theories of modernization from a liberal democratic standpoint, contrary to the leftist standpoint which characterized the so-called dependency theorists. The Dependency theorists assume that western democracy, culture, and capitalism are modern and idle, and these western institutions and values must be exported throughout the rest of the world to aid the development of impoverished nations. If the third world countries don't follow the same development path as their European and United States counterparts, there will be no democracy in these less-developed nations. In this context, should the third world countries wait for the expansion of the middle class, the spread of education, urbanization and so on in order to obtain a liberal democracy? What should we say to our people under fascist dictatorships? That we are not ready for democracy? Theoretically, can this be true?

Basing on these questions, the democratic transition theories were made to support the democratic process in the third world. And democratic transition theorists believe that these preconditions for democratic transition are incorrect. S. Eisenstadt states: "Historically, modernization is the process of change towards those types of social, economic, and political systems that have developed in Western Europe and North America from the seventeenth century to the nineteenth and have then spread to other European countries and in the nineteenth and twentieth centuries to the South American, Asian, and African continents" [11, p. 27].
When the United States of America moved to democracy in the eighteenth century, then the majority of its population was peasantry, and the literacy rate in the United States was not high. What modernization theory required of the Third World countries development of economic growth, urbanization, etc. didn't exist in western Europe and in the U.S.A when they transferred to democracy. Democracy in Europe gradually rose with the expansion of suffrage. What modernization theorists demand from the third world countries - a high level of modernization, urbanization, expansion of the middle class, and a democratic culture for the general public are not preconditions for democracy, but rather they are the results of democracy. What this theory demands from the third world countries is in fact the results of what the U.S.A and western Europe have already obtained when they transferred to democracy in the eighteenth and nineteenth centuries. According to modernization theory, these prerequisites must be present in Latin America and in Asia, and without them democracy can't be held in these countries.

Some political researchers such as Azmi Bishara, see the preconditions for democracy advocated by modernization theory, as part of the Cold War between capitalism represented by the U.S.A and Communism repressed by the Soviet Union. As the United States wanted to justify its alliance with tyrannical governments in the world by saying that these peoples are not ready for democracy, modernization theory in this sense was justification for the alliance with dictatorships in many countries as these countries were not ready for democracy. When the Cold War ended, suddenly these claims evaporated and democracy became permissible even among these backward nations. And alliance with dictatorships is no longer inevitable, because there is no longer the standard for countries to be either with the U.S.A or with communism for alliance with dictatorship. Therefore, the United States is no longer hostile to democracy in its allied countries. These changes in standards open the door widely for the development of the democratic transition studies branch.

Here, Azmi Bishara mentions, that the Cold War ended everywhere in the world except in the Arab region. Bishara refutes the thesis that "the US became a supporter of democratic transformation after the Cold War, and makes the point that the "democratic realism" that guided American policy in the Middle East is a continuation of Cold War policies with new enemies" [12, p. 40]. For the U.S.A the Cold War did not end in the Arab region, and it continued to deal with the region by logic of the Cold War, meaning that it continued to support dictatorships in the Arab region for fear of three things: the willingness to ensure the security of Israel, the chances to lose access to Arab oil and the emergence of terrorist groups which resulted from many reasons, the most impor- 
tant of them were the existence of tyrannical regimes, the Palestine issue and the Arab-Israeli conflict.

Conclusions. Modernization theory soon began to lose support in some academic circles in favor of the theory of democratic transition. As researchers had increasing difficulty in understanding why some nations were unable to achieve the pre-democratic conditions, they became disappointed by ideas of modernization theory. However, the assumptions of modernization theory can be applied in case of consolidation of democracy rather than in case of democratic transition. When talking about consolidating democracy, it becomes clear that it is difficult to consolidate democracy without economic growth and without a certain degree of education, culture, urbanization, the standard of living, the size of the middle class, and so on. After the transition takes place, the new democratic order must be concerned with what modernization theory calls the social and economic conditions for democratic transition.

\section{REFERENCES:}

1. Westover, J. (2018). Shifting Trajectories in Globalization, Labor, and the Transformation of Work. Cambridge Scholars Publishing [in English]

2. Tipps, D.C. (1973). Modernization Theory and the Comparative Study of Societies: A Critical Perspective. [Comparative Studies in Society and History, 15(2), 199-226]. Cambridge University Press [in English]
3. Webster, A. (1984). Introduction to the Sociology of Development. Macmillan International Higher Education [in English]

4. So, A. Y. (1990). Social Change and Development. SAGE Publishing [in English]

5. Chirot, D. (1976). Social Change in a Peripheral Society: [The creation of a Balkan colony]. New York: Academic Press [in English]

6. Lipset, S. M. (1959). Some Social Requisites of Democracy: Economic Development and Political Legitimacy. [The American Political Science Review, Vol. 53, No. 1]. American Political Science Association [in English]

7. Wucherpfennig, J. \& Deutsch F. (2009). Modernization and Democracy: Theories and Evidence Revisited. Living Reviews in Democracy [in English]

8. Moore, B. (2015). Social Origins of Dictatorship and Democracy: Lord and Peasant in the Making of the Modern World. Beacon Press [in English]

9. Przeworski, A., Alvarez, M., Cheibub, J., \& Limongi, F. (1996). What Makes Democracies Endure? [Journal of Democracy, vol. 7 no. 1]. Johns Hopkins University Press [in English]

10. Rostow, W. W. (1959). The Stages of Economic Growth. [The Economic History Review, New Series, Vol. 12, No. 1]. Blackwell Publishing on behalf of the Economic History Society [in English]

11. Hennayake, N. (2006). Culture, Politics, and Development in Postcolonial Sri Lanka. Lexington Books [in English]

12. Bishara, A. (2019). Remarks on External Factors in Democratic Transition. [AlMuntaqa, Vol. 2, No. 2]. Arab Center for Research \& Policy Studies [in English]

\section{Теорія політичної модернізації: критика теоретиків демократичного переходу}

Мустасра Низар Харб

аспірант касредри політології

Харківського національного університету імені В.Н. Каразіна майдан Свободи, 4, Харків, Україна
Зв'язок між теорією модернізації та демократією бере початок від статmі Ліпсета «Деякі соціальні реквізити демократії: економічний розвиток та політичний розвиток» у 1959 році. Ліпсет висунув гіпотезу, що в міру економічного розвитку суспільств їх громадяни більше не терплять репресивних політичних режимів. Зростання ВВП на душу населення, стверджував він, зумовлює перехід до демократії. Теорія модернізації вважає, що економічна сорера пов'язана з державною політикою як одне з найважливіших ії застосувань. Теорія передбачає, що країни третього світу є бідними і традиційними, а західні - багатими і сучасними. I це визначає чіткий курс розвитку для тих бідних країн третього світу, заснований на західних цінностях, спрямований на підвищення рівня життя бідних. Це створює стан залежності від бідних країн до багатих країн. Теорія модернізації передумови демократії вимагають від країн третього світу високого рівня модернізації, урбанізації, експансії середнього класу та демократичної культури для широких верств населення, щоб отримати сучасну демократичну політичну систему. Теоретики демократичного переходу критикують цю теорію та ї̈ передумови для демократії, оскільки деяким країнам важко застосувати ці передумови. Ця стаття зосереджується на аналізі логіки модернізаційної теорії, їі визначеннях, походженні та вимогах до сучасного демократичного суспільства. Вона розглядає теорію модернізачії та їі передумови до демократії шляхом огляду літератури про співвідношення соціально-економічного розвитку та політичної демократії. Вона також концентрується на деякій критиці чієї теорії, висловленої вченими, які вивчали демократичний перехід. Сучасна політична наука зіткнулася з тим, що існує багато критики з боку теоретиків транзитології (між ними також арабські вчені) через труднощі застосування цих передумов традиційними суспільствами з метою переходу до сучасного суспільства та досягнення стабільної демократичної системи.

Ключові слова: теорія модернізації, передумови модернізації, теоретики транзитології, перехід до демократії, стабільна демократична система. 